\title{
Identification and Characterization of Cell-Substratum Adhesion Receptors on Cultured Human Endothelial Cells
}

\author{
Steven M. Albelda," Mildred Daise," Elliot M. Levine," and Clayton A. Buck \\ Cardiovascular Pulmonary Division* Department of Medicine, University of Pennsylvania School of Medicine, and \\ The Wistar Institute ${ }^{\ddagger}$ Philadelphia, Pennsylvania 19104
}

\begin{abstract}
A series of immunological approaches was utilized to identify the molecules involved in cell-substratum adhesion of human endothelial cells (EC) derived from adult large vessels, fat capillaries, and umbilical veins. A polyclonal antibody prepared against partially purified extracellular matrix receptors disrupted adhesion of EC to a wide variety of substrates and identified four groups of glycoproteins migrating with apparent $M_{\mathrm{r}}$ of 150, 125, 110, and $95 \mathrm{kD}$ in immunoprecipitation experiments. Specific monoclonal antibodies identified these proteins as members of the Integrin family of extracellular matrix receptors and included the alpha and beta chains of the fibronectin receptor $\left(\alpha_{5} / \beta_{1}\right)$, a collagen receptor $\left(\alpha_{2} \beta_{1}\right)$, a multifunctional receptor that binds to fibronectin, collagen, and laminin $\left(\alpha_{3} / \beta_{1}\right)$, as well as a receptor related to platelet IIb/ IIIa $\left(\alpha_{v} / \beta_{3}\right)$.

To directly test the importance of these molecules in cellsubstratum adhesion, these proteins were purified by a combination of ion exchange, lectin affinity, and immunoaffinity chromatography and used to block the biological activity of the adhesion-disrupting polyclonal antibody. Immunofluorescence experiments further supported the role of these glycoproteins in adhesion. The GPIIb/IIIa-like receptor localized to wellformed adhesion plaques on EC plated on fibrinogen, but not on fibronectin, laminin, or type IV collagen. Receptors containing the $\beta_{1}$ subunit were visualized as discontinuous fibrils which colocalized with fibronectin fibrils and actin stress fibers.
\end{abstract}

\section{Introduction}

Endothelial cells (EC) ${ }^{1}$ are attached to blood vessel walls in a polarized fashion to form the luminal surface of the vascular system providing a nonthrombogenic permeability barrier be-

Portions of this paper were presented at the American Federation of Clinical Research annual meeting in Washington, D.C., 29 April-2 May, and appeared in abstract form (1988. Clin. Res. 36:502A).

Address reprint requests to Dr. Albelda, 975 Maloney Building, Hospital of the University of Pennsylvania, 3600 Spruce Street, Philadelphia, PA 19104.

Received for publication 10 June 1988 and in revised form 23 January 1989.

1. Abbreviations used in this paper: EC, endothelial cell(s); ECM, extracellular matrix; TNC, Tris/NP-40/calcium buffer; VLA, very late antigen; WGA, wheat germ agglutinin.

J. Clin. Invest.

(c) The American Society for Clinical Investigation, Inc.

$0021-9738 / 89 / 06 / 1992 / 11 \quad \$ 2.00$

Volume 83, June 1989, 1992-2002 tween the blood and extravascular tissues (1). In this capacity, they are subjected to large shear forces and changes in hydrostatic pressures. Since disruption of EC adhesion can lead to tissue edema, as well as the attachment of platelets and leukocytes to the normally inaccessible subendothelial matrix (2), an understanding of the factors that control normal EC adhesion to the substratum has great importance in a wide variety of disease states such as atherosclerosis or the adult respiratory distress syndrome.

Endothelial cells can attach and spread on a number of substrates in vitro including fibronectin, gelatin, collagens, fibrinogen, laminin, von Willebrand's factor, and vitronectin, as well as to the basement membrane produced by other cells in culture (3-7). The actual mechanism by which EC attach to these extracellular matrix molecules is not known. It is likely, however, that this process is mediated by members of the recently defined family of cell surface glycoproteins, designated "integrins," (8) which serve as cell adhesion receptors. These receptors, which bridge the cytoskeletal elements of a cell to the extracellular matrix (ECM), are glycoproteins consisting of an $\alpha$ subunit (120-200 kD) noncovalently bound to a highly disulfide cross-linked $\beta$ subunit (80-120 kD) (8-10). The integrin family is made up of several subfamilies of receptors, each subfamily being defined by a common $\beta$ subunit $(8,9)$. The specificity for individual ECM molecules arises from the association of the common $\beta$ subunit with different $\alpha$ subunits within each family. Members of the Integrin family, grouped according to homology in their $\beta$ subunits include: $(a)$ the avian integrin receptors (11), the mammalian fibronectin receptor $(12,13)$, a laminin receptor (14), at least two types of collagen receptors (15), and the very late antigens (VLA) (16); (b) the Leu-CAMS, including leukocyte membrane proteins LFA-1, Mac-1, and p150/90 (17); and (c) the cytoadhesins (18) which include platelet glycoproteins GPIIb/IIIa (19) and the mammalian vitronectin receptor (20).

To date, the repertoire of cell-substratum adhesion receptors present on the EC has not been defined with the exception of a receptor related to the platelet IIb/IIIa glycoprotein complex (21-29). Recent work has shown that antibodies directed against the platelet IIb/IIIa complex can affect the adhesion of umbilical vein endothelial cells to certain substrates (22-24). The purpose of this report was to further identify and characterize proteins on the surface of a variety of human EC which might function as extracellular matrix receptors.

\section{Methods}

Cell culture. Human adult large vessel and umbilical vein EC were isolated and cultured as previously described (30-32). Iliac artery or vein segments were obtained from renal transplant donors. Adult fat capillary EC were kindly provided by Dr. Stuart Williams (Thomas Jefferson University, Philadelphia). These cells were derived from human fat tissue removed by liposuction using previously described 
techniques (33). An endothelial cell identity was confirmed by morphology, immunofluorescent staining for factor VIII-related antigen, and detection of angiotensin-converting enzyme activity (30, 34). All cultures were tested periodically and found to be free of mycoplasma infection (34). Some umbilical vein cultures were not passaged but used as primary cultures.

Antibodies. A complete listing of antibodies used in these studies, including their documented specificities and their sources, is found in Table I.

The following polyclonal antisera were used: $(a)$ hamster antiGP140, raised in goats against the 140-kD cell adhesion glycoproteins isolated from $\mathrm{BHK}_{21} / \mathrm{C}_{13}$ cells (35); this antibody has been shown to cause reversible alterations in cell adhesion and spreading in a number of mammalian cell types (35-37); (b) rat anti-GP140, an antiserum raised in a rabbit against the $140-\mathrm{kD}$ adhesion receptor complex present in the rat L6A cell line prepared as previously described (11); (c) a polyclonal anti-hamster fibronectin receptor antibody raised in goats (kindly provided by Dr. R. L. Juliano) (13); and (d) a polyclonal rabbit antibody raised against the chicken integrin molecule (38).

A monoclonal antibody raised against platelet glycoprotein IIIa $\left(\beta_{3}\right.$ subunit) was provided by Dr. Joel Bennett and Dr. James Hoxie of the University of Pennsylvania (39).

The following monoclonal antibodies were kindly provided by Drs. Elizabeth Wayner and William Carter (15): P1H5, directed against the $\alpha$ subunit of a collagen-specific adhesion receptor (anti-class II ECM receptor); P1B5, directed against the $\alpha$ subunit of a multifunctional cell adhesion receptor with activity against cells plated on fibronectin, laminin, and collagen (anti-class I ECM receptor); and P1D6, directed against the $\alpha$ subunit of the mammalian fibronectin receptor (40). It should be noted that the ECM class II receptor corresponds to VLA-2 and the ECM class I receptor corresponds to VLA-3 (41).
Dr. Martin Hemler provided the following monoclonal antibodies $(16,42)$ : A-1A5, directed against the $\beta$ subunit of the VLA antigens; TS2/7, which recognizes the VLA- 1 complex; and B-5H10, directed against the VLA-4 complex.

Use of antibodies to inhibit EC adhesion. Tissue culture plates (96-well) were coated with purified matrix substances. Laminin (provided by Dr. Hynda Kleinman, National Institutes of Health, Bethesda, MD) was dissolved in sterile water (final concentration 10 $\mu \mathrm{g} / \mathrm{ml}$ ). Type IV/V collagen, prepared from human placentas (the gift of Dr. Stuart Williams) was prepared by diluting a $1-\mathrm{mg} / \mathrm{ml}$ stock solution (in $1 \mathrm{mM}$ acetic acid) into a $0.05 \mathrm{M}$ sodium carbonate buffer (final concentration $10 \mu \mathrm{g} / \mathrm{ml}$ ). Each of these solutions was added to the tissue culture plate and allowed to incubate at $37^{\circ} \mathrm{C}$ overnight. Human fibronectin (New York Blood Center) (final concentration 10 $\mu \mathrm{g} / \mathrm{ml}$ ) and gelatin (1\%) dissolved in PBS were added to the plates and incubated for $2 \mathrm{~h}$ at $37^{\circ} \mathrm{C}$. $30 \mathrm{~min}$ before each experiment, each well was aspirated, washed twice with PBS, and then flooded with medium M199 supplemented with $2.5 \mathrm{mg} / \mathrm{ml}$ of BSA to block nonspecific binding. Immediately before adding the cells, the media in each well was replaced with $100 \mu \mathrm{l}$ of complete tissue culture media containing various dilutions of hamster or rat anti-GP140. EC were trypsinized and $5 \times 10^{3}$ cells, suspended in $100 \mu$ l of complete media, were added to each well. After $18 \mathrm{~h}$, wells were scored for the presence of rounded cells.

The initial adhesion of EC to various matrix proteins in the presence of antibodies was also studied. To prevent the synthesis of EC matrix proteins during the initial adhesion period, confluent flasks of endothelial cells were refed with complete tissue culture media containing cycloheximide $(25 \mu \mathrm{g} / \mathrm{ml}) 1 \mathrm{~h}$ before each experiment. This concentration of cycloheximide has been shown to effectively inhibit protein synthesis while maintaining cell viability over the short term

Table I. Antibodies Used to Identify EC Adhesion Receptors

\begin{tabular}{|c|c|c|c|}
\hline Anti-receptor antibody & Description & Reference & $\begin{array}{l}\text { ECM specificity of receptor(s) } \\
\text { recognized by antibody }\end{array}$ \\
\hline Anti-hamster GP140 & Polyclonal against partially purified hamster ECM receptor & $(35)$ & $\begin{array}{l}\text { Fibronectin } \\
\text { Fibrinogen } \\
\text { Type IV collagen } \\
\text { Lamin } \\
\text { Gelatin }\end{array}$ \\
\hline Anti-rat GP140 & Polyclonal against partially purified rat ECM receptor & $(11)$ & Same as above \\
\hline Anti-hamster fibronectin receptor & $\begin{array}{l}\text { Polyclonal against purified fibronectin receptor from } \\
\text { hamster cells }\end{array}$ & (13) & Fibronectin \\
\hline Anti-avian integrin & Polyclonal against purified avian integrin complex & $(38)$ & $\begin{array}{l}\text { Fibronectin } \\
\text { Collagen } \\
\text { Laminin }\end{array}$ \\
\hline Anti-GPIIIa & Monoclonal against human platelet GPIIIa ( $\beta_{3}$ subunit $)^{*}$ & (39) & $\begin{array}{l}\text { Fibrinogen } \\
\text { Vitronectin } \\
\text { von Willebrand factor }\end{array}$ \\
\hline PIH5 & $\begin{array}{l}\text { Monoclonal against the } \alpha \text { chain of the class II ECM } \\
\text { receptor (also known as VLA-2, platelet GP Ia or } \alpha_{2} \text { ) }\end{array}$ & $(15)$ & Collagen \\
\hline PIB5 & $\begin{array}{l}\text { Monoclonal against the } \alpha \text { chain of the class I ECM } \\
\text { receptor (also known as VLA-3, GPIc, or } \alpha_{3} \text { ) }\end{array}$ & $(15)$ & $\begin{array}{l}\text { Collagen } \\
\text { Laminin } \\
\text { Fibronectin }\end{array}$ \\
\hline PID6 & $\begin{array}{l}\text { Monoclonal against the } \alpha \text { chain of the fibronectin receptor } \\
\text { (also known as VLA-5, or } \alpha_{5} \text { ) }\end{array}$ & $(15)$ & Fibronectin \\
\hline AlA5 & $\begin{array}{l}\text { Monoclonal against common } \beta \text { chain of VLA antigens ( } \beta_{1} \\
\text { subunit, also known as platelet GPIIa) }\end{array}$ & $(42)$ & $\begin{array}{l}\text { Fibronectin } \\
\text { Collagen } \\
\text { Laminin }\end{array}$ \\
\hline $\mathrm{TS} 2 / 7$ & Monoclonal against the $\alpha$ chain of VLA-1 $\left(\alpha_{1}\right)$ & $(16)$ & Unknown \\
\hline B-5G10 & Monoclonal against the $\alpha$ chain of VLA-4 $\left(\alpha_{4}\right)$ & $(16)$ & Unknown \\
\hline
\end{tabular}

* For description of $\alpha$ and $\beta$ subunits, see Hynes (8). 
(25). After washing each flask twice with PBS, the cells were detached with $0.25 \%$ trypsin $/ 0.04 \%$ EDTA dissolved in calcium/magnesiumfree Hanks' balanced salt solution. The trypsin was neutralized by adding an equal volume of medium M199 containing $2.5 \mathrm{mg} / \mathrm{ml} \mathrm{BSA}$ and $0.5 \%$ soy trypsin inhibitor (Worthington Biochemical Corp., Freehold, NJ), and the cell suspension was centrifuged and resuspended in M199/2.5 mg/ml BSA at a density of $1.6 \times 10^{5}$ cells $/ \mathrm{ml}$. $250-\mu \mathrm{l}$ aliquots of cell suspension were added to $2-\mathrm{cm}^{2}$ non-tissue culture plastic wells coated with various substrates (see above) to which $250 \mu \mathrm{l}$ of complete tissue culture media containing a 1:25 dilution of anti-GP140 had already been added (final dilution of antibody was thus 1:50). After $3 \mathrm{~h}$ the media were aspirated, each well was washed twice with PBS, and the adherent cells were removed with trypsinEDTA and counted electronically.

Cell harvest and NP-40 extraction. After achieving confluence in gelatinized $180-\mathrm{cm}^{2}$ tissue culture flasks, EC were harvested by treatment with a solution of 5 mM EDTA and $2 \mathrm{mM}$ PMSF in PBS for 15 min followed by scraping. Cell pellets of $\sim 5 \times 10^{7}$ cells were frozen at $-70^{\circ} \mathrm{C}$. Membrane extracts were prepared by adding small volumes of $0.01 \mathrm{M}$ Tris acetate, $\mathrm{pH} 8.0,0.5 \% \mathrm{NP}-40,0.5 \mathrm{mM} \mathrm{Ca}^{2+}$ (TNC) with 2 $\mathrm{mM}$ PMSF to the pellet, pipetting on ice for $15 \mathrm{~min}$, and then centrifuging for $40 \mathrm{~min}$ at $18,000 \mathrm{rpm}$ in the SS 34 head of a centrifuge (model RC2-B, DuPont-Sorval, Newtown, CT). The resulting supernatant was called the NP-40 extract and frozen at $-70^{\circ} \mathrm{C}$ until used.

Labeling of cells. NP-40 extracts of cells used for immunoprecipitation were prepared by washing EC in confluent $180-\mathrm{cm}^{2}$ tissue culture flasks with PBS. The cells were then exposed to Dulbecco's modified Eagle's medium without methionine, supplemented with EC growth factor and heparin, in the presence of $10 \%$ dialyzed, heat-inactivated fetal bovine serum for $1 \mathrm{~h}$. At this time, fresh media containing $200 \mu \mathrm{Ci}$ of ${ }^{35} \mathrm{~S}$-labeled methionine (New England Nuclear, Boston, MA) were added. After 24-48 h, the cells were harvested and extracted as described above.

Immunoprecipitation and gel electrophoresis. NP-40 extracts or more purified preparations were preadsorbed with Sepharose 4B for 30 min at $4^{\circ} \mathrm{C}$. $100 \mu \mathrm{l}$ of this antigen solution was reacted with $50 \mu \mathrm{l}$ of antibody solution or preimmune serum for $1 \mathrm{~h}$ at $4^{\circ} \mathrm{C}$. Immunocomplexes, collected by precipitation with protein A conjugated to Sepharose beads for $1 \mathrm{~h}$ at $4^{\circ} \mathrm{C}$, were washed and then dissolved in electrophoresis sample buffer (62.5 mM Tris base, $2 \%$ SDS, $10 \%$ glycerol, pH 6.8). Samples were analyzed by SDS-PAGE using $6 \%$ or $7 \%$ polyacrylamide gels (43) without the use of reducing agents. Gels were impregnated with $\mathrm{En}^{3} \mathrm{Hance}$ (New England Nuclear) and exposed to XR-5 $\mathrm{x}$-ray film (Eastman Kodak Co., Rochester, NY) at $-70^{\circ} \mathrm{C}$.

Blocking assay. This assay was based on the assumption that any material in the NP-40 extract (or other fractions) capable of blocking the ability of the anti-GP140 to prevent EC adhesion and spreading must contain components related to the maintenance of adhesion $(35,44)$.

The concentration of hamster anti-GP140 required to inhibit the adhesion and spreading of endothelial cells plated on gelatin was determined by plating $\sim 1.5 \times 10^{4}$ cells $/ \mathrm{cm}^{2}$ into tissue culture medium containing various dilutions of the antibody. After $18 \mathrm{~h}$, wells were scored for the presence of rounded cells. Although we found that activity was detectable at dilutions of up to $1: 100$, for purposes of a screening assay, we routinely used the antibody at 1:50 dilution, a concentration that induced rounding in $90-100 \%$ of the cells.

NP-40 extracts to be tested for blocking activity were processed as previously described (35). Samples were added to individual wells of a 96-well microtiter plate (that had been precoated with gelatin, fibronectin, fibrinogen, type IV collagen, or laminin) followed by $100 \mu \mathrm{l}$ of tissue culture medium containing a 1:25 dilution of anti-GP140 (making a final antibody concentration of 1:50). Approximately 7 $\times 10^{3}$ cells in a volume of $10-20 \mu \mathrm{l}$ were then added to each well. Wells were scored $18 \mathrm{~h}$ later for inhibition of rounding which reflected the ability of the antigen to block the activity of the antibody.

Purification of NP-40 extracts. 1-3 ml of NP-40 extract (which had been dialyzed for $18 \mathrm{~h}$ against TNC buffer to remove residual salt) was applied to an Affigel 102 (35) column and fractions were collected at about $1 \mathrm{ml}$ every $5 \mathrm{~min}$. The column was washed with TNC buffer and then eluted with buffer containing $0.01,0.05,0.1,0.5$, and $1.0 \mathrm{M} \mathrm{NaCl}$, respectively. Each fraction $(1.0 \mathrm{ml})$ was monitored for radioactivity and bioactivity in the blocking assay. Active fractions from the Affigel 102 column were pooled and applied to a wheat germ agglutinin (WGA) column followed by extensive washing with TNC/0.15 M $\mathrm{NaCl}$. Bound material was eluted using $0.2 \mathrm{M} \mathrm{N}$-acetyl-D-glucosamine in TNC buffer in 1-ml fractions which were monitored for radioactivity and bioactivity. Active fractions from the WGA column eluates were pooled and applied to a column containing $1 \mathrm{ml}$ of antiplatelet glycoprotein IIIa antibody coupled to Sepharose which had been preequilibrated with TNC buffer containing $0.15 \mathrm{M} \mathrm{NaCl}$. After extensive washing with buffer, bound material was eluted with $50 \mathrm{mM}$ diethylamine in $0.01 \mathrm{M}$ Tris acetate, $0.5 \mathrm{mM} \mathrm{Ca}^{2+}, 0.05 \% \mathrm{NP}-40$ that had been adjusted to $\mathrm{pH}$ 11.5. Each $1-\mathrm{ml}$ fraction was neutralized, dialyzed against TNC/ $0.15 \mathrm{M} \mathrm{NaCl}$ overnight at $4^{\circ} \mathrm{C}$, and tested for bioactivity.

Immunofluorescence. EC were plated at subconfluent densities on glass coverslips coated with various matrix substance as described above. Two protocols were used for plating the EC. In the first, the cells were dispersed with trypsin/EDTA, the trypsin was neutralized with soy trypsin inhibitor, and the cells were resuspended and plated in serum-free medium M199 with $2.5 \mathrm{mg} / \mathrm{ml} \mathrm{BSA}$ and fixed $3 \mathrm{~h}$ later. In some experiments, $25 \mu \mathrm{g} / \mathrm{ml}$ of cyclohexamide was added $1 \mathrm{~h}$ before typsinization and was present throughout the incubation period. In the second, the trypsin/EDTA was neutralized, with medium-containing serum, and the cells were plated in complete medium M199 and then processed for immunofluorescent staining after $18 \mathrm{~h}$. Staining was performed using the method of Damsky et al. (38). Briefly, cells were fixed with $3 \%$ paraformaldehyde and permeabilized with $1 \%$ NP-40 for $1 \mathrm{~min}$. Antibody or preimmune serum was added for $1 \mathrm{~h}$ and after rinsing, the cells were stained with a 1:200 dilution of fluorescein-labeled anti-mouse or rhodamine anti-goat antibodies for $1 \mathrm{~h}$. Cells were viewed on a phase-epifluorescent microscope (Carl Zeiss, Inc., Thornwood, NY) using a $63 \times$ planapochromat oil-immersion lens numerical aperture 1.4 and photographed using Tri-X film.

\section{Results}

Effect of anti-adhesion receptor antibodies on EC adhesion. To determine the activity of anti-GP140 on initial adhesive events, cells were plated onto different substrates in the presence or absence of anti-hamster GP140. As shown in Fig. 1, initial adherence ( $3 \mathrm{~h}$ after plating) of EC to laminin, type IV collagen, and fibronectin was affected only slightly by the antibody, whereas there were marked inhibitory effects on cells plated on fibrinogen or gelatin. After $18 \mathrm{~h}$ of exposure, however, there was complete detachment of cells plated on laminin, collagen, and fibronectin. A typical example is shown in Fig. 2. A similar effect was noted in experiments using the anti-rat GP140 antiserum. Preimmune serum had no effects on cell adhesion. The actions of the antisera were blocked by nonionic detergent extracts of endothelial cells (Fig. 2). When the antisera were removed from the media, the remaining cells reverted to their normal morphology, demonstrating that the effect was not due to irreversible cytotoxicity.

Identification of EC surface proteins reactive with adhesion-disrupting antisera. Nonionic detergent extracts of $\left[{ }^{35} \mathrm{~S}\right]-$ methionine-labeled EC were immunoprecipitated with the antibodies that perturbed cell-substrate adhesion (anti-hamster and rat GP140). These antisera precipitated polypeptides migrating in the molecular mass range of $150,125,110$, and 95 $\mathrm{kD}$ from human adult large vessel endothelial cells (Fig. 3, lanes $a, b$, and $e$ ), adult human fat capillary cells (Fig. 4, lower panel, lane $a$ ) primary umbilical vein endothelial cells (Fig. 4, 


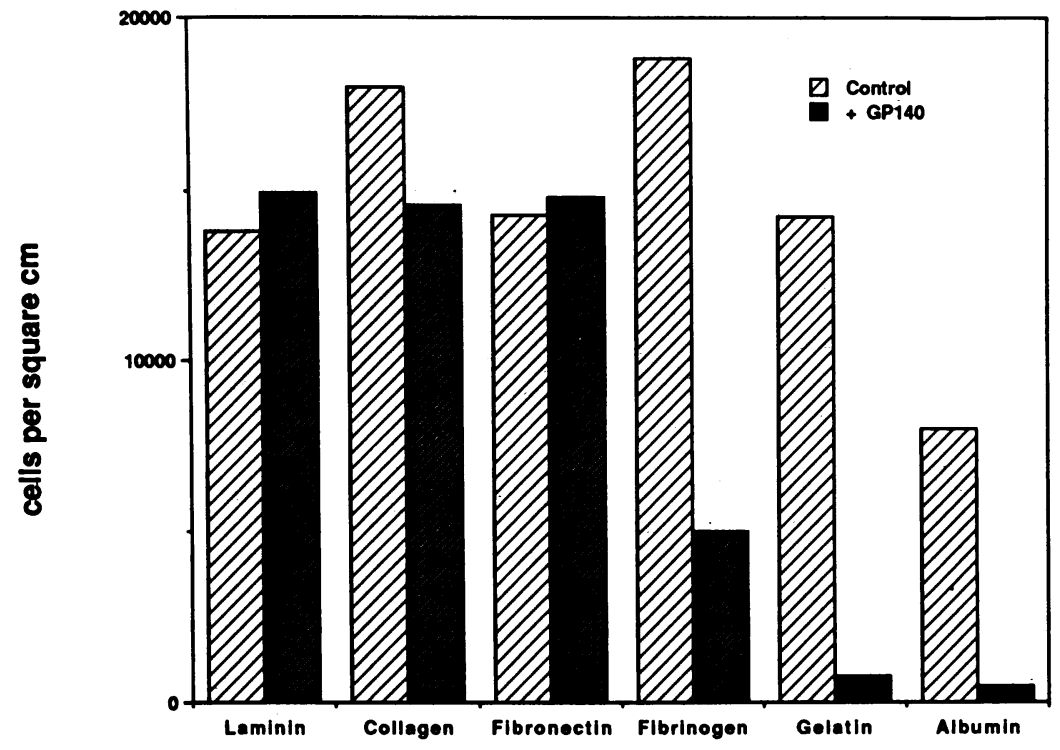

SUBSTRATES
Figure 1. Effect of anti-GP140 on initial adhesion to a variety of substrates. Purified matrix substances were adhered to 24-well non-tissue plastic culture plates. $250 \mu$ l of complete tissue culture media (control) or $250 \mu$ l of complete media containing a 1:25 dilution of anti-GP140 were added to the substratecoated wells followed by the addition of $4 \times 10^{4}$ trypsinized EC suspended in $250 \mu \mathrm{l}$ of complete media. After $3 \mathrm{~h}$, the wells were washed twice with PBS and the cells counted electronically. Initial adhesion of EC to laminin, type IV collagen, or fibronectin was relatively unaffected. In contrast, anti-GP140 had marked effects on the initial adhesion of EC to fibrinogen and gelatin. upper panel, lane $a$ ) and passaged umbilical vein cells (data not shown).

Monoclonal antibodies known to be specific for subunits of the integrin family of receptors were used to further identify these glycoproteins (Table I, Figs. 3 and 4). A monoclonal antibody reactive with GPIIIa (anti- $\beta_{3}$ ) from human platelets (39) immunoprecipitated two glycoproteins corresponding to the 150 - and $95-\mathrm{kD}$ polypeptides precipitated by the antiGP140 antibodies (Fig. 3, lane $d$; Fig. 4, lane $b$ ). These proteins almost certainly represent the platelet glycoprotein IIb/IIIalike complex from endothelial cells previously described by others (21, 26-29). A monoclonal antibody directed against the common $\beta_{1}$ subunit (A-1A5) immunoprecipitated two bands that had molecular masses of 150 and $125 \mathrm{kD}$ (Fig. 3, lane $i$ ). This immunoprecipitate also contained a $110-\mathrm{kD}$ protein which may represent a precursor of the $125-\mathrm{kD}$ subunit reported by us and others $(45,46)$ or a yet unidentified subunit. The monoclonal antibodies directed against the $\alpha$ subunit of class I (P1B5) and class II (P1H5) ECM receptors, as well as the fibronectin receptor (P1D6); also precipitated bands at 150 and $125 \mathrm{kD}$ (Fig. 3, lanes $f-h$; Fig. 4, lanes $c-e$ ). Monoclonal antibodies against VLA-1 and VLA-4 did not immunoprecipitate proteins from the endothelial cells (Fig. 3, lanes $j$, $k$ ). The polyclonal antibody against the hamster fibronectin receptor also precipitated two proteins, but the molecular masses were 125 and $110 \mathrm{kD}$ (Fig. 3, lane $c$ ). A weak band was also seen at $150 \mathrm{kD}$. The lower two bands correspond exactly to the middle bands immunoprecipitated by both anti-GP140 antibodies. The polyclonal antibody against the avian integrin receptor immunoprecipitated proteins of the same molecular mass as the anti-GP140 antibodies (data not shown):

The identity of the lower molecular mass protein immu-

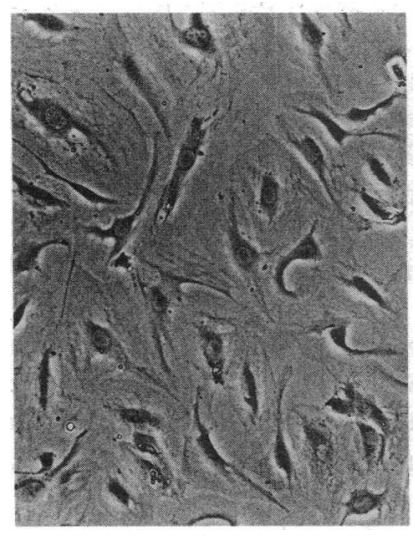

Control

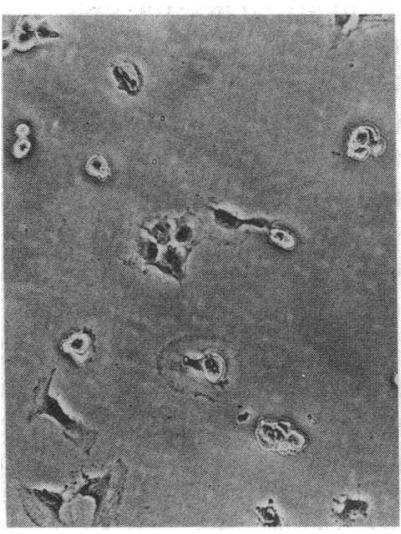

Anti-GP 140

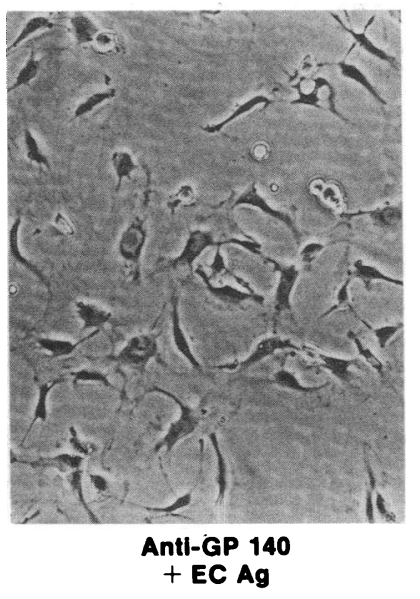

Figure 2. Long-term effect of the anti-GP140 on the adhesion of adult human large-vessel endothelial cells to gelatin. Adult human large-vessel EC were plated into a 96-well culture plate coated with $1 \%$ gelatin at a density of $1.5 \times 10^{4}$ cells $/ \mathrm{cm}^{2}$ in complete culture media (control), in the presence of antiGP140 at a dilution of $1: 50$, or in the presence of a 1:50 dilution of anti-GP140 with the addition of an EC membrane extract. After $18 \mathrm{~h}$ under control conditions (left), EC adhere and spread normally. In the presence of anti-GP140 (middle), few EC adhere and those that do attach fail to spread normally. The addition of EC extract to medium containing anti-GP140 (right), however, blocks the antibody-mediated adhesion disrupting activity. 


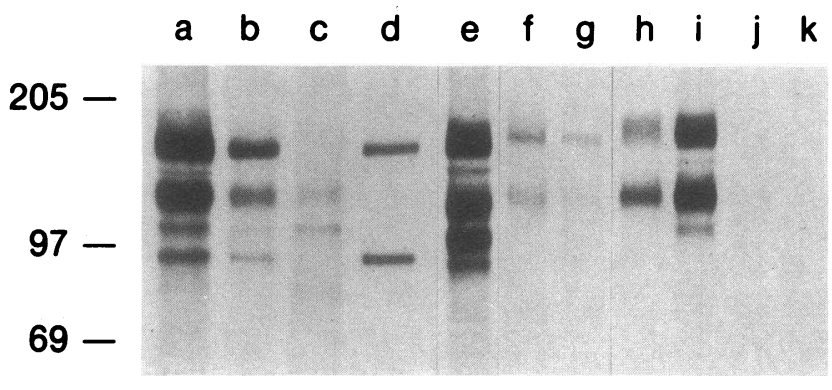

Figure 3. Material immunoprecipitated from large-vessel EC extracts by antiadhesion receptor antibodies. NP 40 extracts of $\left[{ }^{35} \mathrm{~S}\right]-$ methionine-labeled EC were immunoprecipitated as described in Methods using the following antibodies (see Table I): lanes $a, e$, polyclonal rat anti-GP140; lane $b$, polyclonal hamster anti-GP140; lane $c$, polyclonal purified anti-hamster fibronectin receptor; lane $d$, monoclonal anti- $\beta_{3}$; lane $f$, P1H5 (monoclonal against the $\alpha$ chain of the type II ECM receptor [VLA-2]); lane $g$, P1B5 (monoclonal against the $\alpha$ chain type I ECM receptor [VLA-3]); lane $h$, P1D6 (monoclonal against the $\alpha$ chain of the fibronectin receptor [VLA-5]); lane $i$, A-1A5 (monoclonal against the common VLA $\beta_{1}$ chain), lane $j$, TS $2 / 7$ (monoclonal against the $\alpha$ chain of VLA-1); and lane $k, \mathrm{~B}-5 \mathrm{G} 10$ (monoclonal against the $\alpha$ chain of VLA-4). Samples were electrophoresed on a $6 \%$ SDS-polyacrylamide gel under nonreducing conditions and autoradiographed. Lanes $a-d$ were from the same gel; lanes $e-k$ were from a different gel. Molecular mass markers in kilodaltons are on the left.

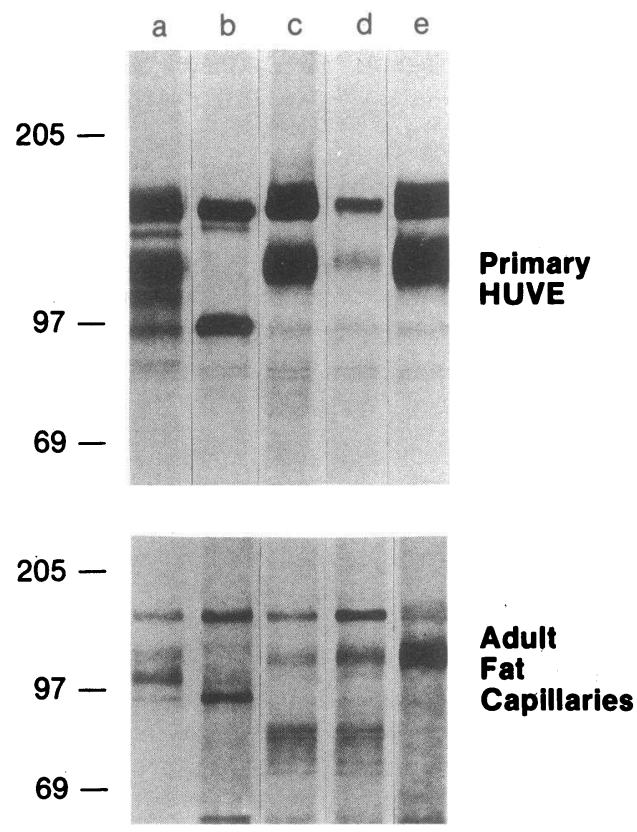

Figure 4. Material immunoprecipitated from primary human umbilical vein EC (top) or EC derived from adult human fat capillaries (bottom). NP-40 extracts of $\left.{ }^{35} \mathrm{~S}\right]$ methionine-labeled cells were immunoprecipitated as described in Methods using the following antibodies (see Table I): lane $a$, anti-GP140; lane $b$, monoclonal anti- $\beta_{3}$; lane $c$, P1H5 (monoclonal against the $\alpha$ chain of the type II ECM receptor [VLA-2]; lane $d$, P1B5 (monoclonal against the $\alpha$ chain of the type I ECM receptor [VLA-3]; lane $e$, P1D6 (monoclonal against the $\alpha$ chain of the fibronectin receptor [VLA-5]. Samples were electrophoresed on a $6 \%$ SDS-polyacrylamide gel under nonreducing conditions. Molecular mass markers in kilodaltons are on left.

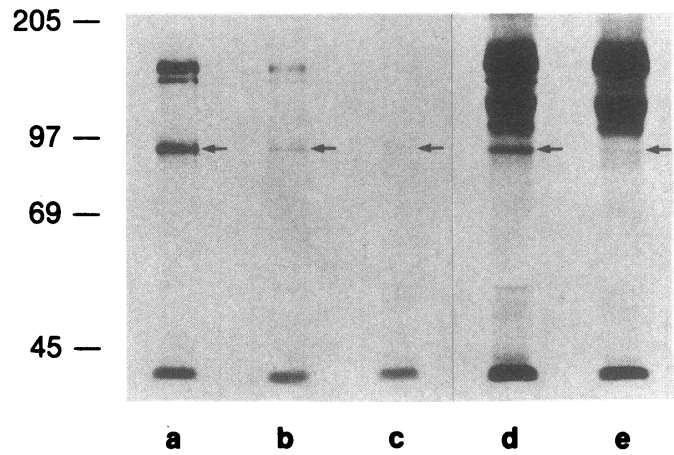

Figure 5. Sequential immunoprecipitation of EC extracts by the anti-GPIIIa monoclonal antibody. NP-40 extracts of $\left[{ }^{35} \mathrm{~S}\right]-$

methionine-labeled EC were prepared as described in Methods. An aliquot of the labeled extract was subjected to three cycles of immunoprecipitation as follows: lane $a$, antiplatelet GPIIIa monoclonal antibody was used to precipitate antigen from extract; lane $b$, the extract was then reprecipitated with anti-IIIa monoclonal antibody to remove residual IIb/IIIa-like protein; lane $c$, the extract from lane $b$ was reprecipitated with the anti-IIIa monoclonal antibody demonstrating complete removal of the proteins reactive with this antibody; lane $e$, the "cleared" extract from lane $b$ was immunoprecipitated with polyclonal rat antifibronectin receptor antibody; lane $d$, fresh, "uncleared" extract immunoprecipitated with rat antifibronectin receptor antibody. Samples were electrophoresed on a 7\% SDS-polyacrylamide gel, under nonreducing conditions, and autoradiographed. Molecular mass markers in kilodaltons are on the left. A comparison of lanes $d$ and $e$ shows that all of the $95-\mathrm{kD}$ protein was removed by the anti-IIIa monoclonal antibody (arrows), however, most of the material at $150 \mathrm{kD}$, as well as the material migrating at 110 and $125 \mathrm{kD}$, remains.

noprecipitated by the polyclonal antibodies was further confirmed by sequential immunoprecipitation experiments (Fig. 5). A comparison of rat anti-GP140 immunoprecipitates from an "uncleared" extract (Fig. 5, lane $d$ ) vs. the same extract previously "cleared" with anti- $\beta_{3}$ antibody (Fig. 5, lane $e$ ) shows that the $95-\mathrm{kD}$ band was removed by reaction with the anti- $\beta_{3}$ monoclonal antibody, while most of the $150-\mathrm{kD}$ material, as well as the proteins migrating in the $110-$ and $125-\mathrm{kD}$ region of the gel, remained.

Sequential immunoprecipitation experiments were also performed using the $\beta_{1}$-specific monoclonal antibody, A-1A5 (Fig. 6). Extracts were immunoprecipitated three times with A-1A5 (Fig. 6, lanes $a-c$ ) to remove proteins reactive with this antibody. When the precleared material was immunoprecipitated with rat anti-GP140 (Fig. 6, lane $e$ ) and compared with the material immunoprecipitated from "uncleared" extract (Fig. 6, lane $d$ ), the 125-kD band was absent, as was most of the material migrating in the $150-\mathrm{kD}$ region of the gel, leaving the bands at 95 and $110 \mathrm{kD}$, and a faint band at $150 \mathrm{kD}$. These results further show that the $125-\mathrm{kD}$ band represents the $\beta_{1}$ subunit common to the fibronectin receptor and the VLA family of receptors.

Purification of an EC adhesion receptor. To further confirm that these proteins are important in EC-ECM adherence, we took advantage of the fact that the inhibition of adhesion and spreading of EC on gelatin mediated by anti-GP140 could be blocked by the addition of a nonionic detergent extract of EC (Fig. 2). We used this inhibition as a bioassay to purify EC membrane components important in cell adhesion. 


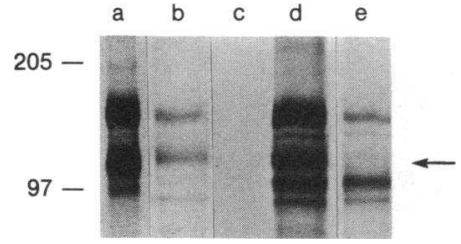

Figure 6. Sequential immunoprecipitation of EC extracts by the A-1A5 monoclonal antibody directed against the VLA common $\beta$ subunit. NP-40 extracts of $\left[{ }^{35} \mathrm{~S}\right]$ methioninelabeled EC were prepared. An aliquot of the labeled extract was subjected to three cycles of immunoprecipitation as follows: lane $a, \mathrm{~A}-1 \mathrm{~A} 5$ monoclonal antibody was used to precipitate antigen from extract; lane $b$, the extract was then reprecipitated with A-1A5 to remove residual protein reacting with this antibody; lane $c$, the extract from lane $b$ was reprecipitated with the A-1A5 monoclonal antibody demonstrating complete removal of the $\beta_{1}$ subunit; lane $e$, the "cleared" extract from lane $b$ was immunoprecipitated with polyclonal rat antifibronectin receptor antibody; lane $d$, fresh, "uncleared" extract was immunoprecipitated with rat antifibronectin receptor antibody. Samples were electrophoresed on a 6\% SDS-polyacrylamide gel, and autoradiographed under nonreducing conditions. Molecular mass markers in kilodaltons are on the left. A comparison of lanes $d$ and $e$ shows that all of the 125$\mathrm{kD}$ protein was removed by the anti- $\beta$ chain monoclonal antibody (arrows), however, a small amount of material at $150 \mathrm{kD}$ as well as the material migrating at 110 and $95 \mathrm{kD}$ remains.

Table II summarizes the results of three purification procedures performed with a mixture of nonionic detergent extracts from unlabeled and $\left[{ }^{35} \mathrm{~S}\right]$ methionine-labeled EC. The material that eluted from the Affigel column with $0.05 \mathrm{M}$ $\mathrm{NaCl}$ contained all the blocking activity. When this active fraction was passed over the WGA-lectin column, all the activity was found in the material adherent to the column. SDSPAGE followed by either autoradiography or silver staining of the active material eluted from the Affigel (Fig. $7 a$ ) and the WGA columns (Fig. $7 b$ ) revealed that this two-step purification resulted in a preparation enriched in polypeptides migrating in the 150-, 125-110-, and 95-kD region of the gel. Immunoblotting experiments using this purified material showed cross reactivity with the antiplatelet GPIIIa monoclonal antibody (95-kD band), polyclonal antibodies to rat anti-GP140 (110- and 125-kD bands) and to avian integrin (110-, 125-, and $150-\mathrm{kD}$ bands).
Figure 7. SDS-PAGE of material containing blocking activity. Material eluted from the Affigel 102 column by $0.05 \mathrm{M} \mathrm{NaCl}$ (lane $a$ ), material eluted from the WGA column by $\mathrm{N}$-acetyl-glucosamine (lane $b$ ), and material eluted from the antiplatelet GPIIIa monoclonal antibody column (lane $c$ ) was electrophoresed on a 7\% SDSpolyacrylamide gel under nonreducing conditions, and stained for protein using the silver nitrate reagent. Molecular mass markers in kilodaltons are on the left. The band visualized at $69 \mathrm{kD}$ represents albumin contamination in the sample buffer.

To further purify this complex, the material was passed over an affinity column made from the anti- $\beta_{3}$ monoclonal antibody. Upon elution with diethylamine, the material that bound to the column revealed only the 150 - and $95-\mathrm{kD}$ proteins (Fig. 7 c). Not surprisingly, the lower molecular mass protein cross reacted with the anti-GPIIIa monoclonal antibody in immunoblots. SDS-PAGE of the material passing through the anti- $\beta_{3}$ monoclonal column revealed proteins that migrated in the 150-, 125-, and 110-kD regions of the gel, but no material in the $95-\mathrm{kD}$ region, confirming the results of the immunoadsorption experiments.

The glycoproteins eluted from the WGA column, the purified IIb/IIIa-like complex, and the material that passed through the anti-IIIa monoclonal antibody column were assayed for their ability to block the effects of anti-GP140 on a variety of substrates, in addition to gelatin (Table II). The material eluted from the WGA column and the material that passed through the anti-IIIa monoclonal antibody column neutralized the effect of anti-GP140 on all substrates. In contrast, the $150 / 95-\mathrm{kD}$ dimer eluted from the anti-IIIa monoclonal antibody column blocked the effects of anti-GP140 when EC were plated on fibrinogen and gelatin but not when plated on fibronectin, collagen, or laminin. This suggests that the

Table II. Purification of EC Adhesion Receptor

\begin{tabular}{|c|c|c|c|c|c|c|}
\hline \multirow[b]{2}{*}{ Extract } & \multirow[b]{2}{*}{$\begin{array}{l}\text { Percent total } \\
{ }^{35} \mathrm{~S} \text { counts }\end{array}$} & \multicolumn{5}{|c|}{ Blocking activity } \\
\hline & & Gelatin & Fibrinogen & Laminin & Fibronectin & Collagen (type IV) \\
\hline Total membrane & 100 & + & + & + & + & + \\
\hline \multicolumn{7}{|l|}{ Affigel 102 column } \\
\hline $0.05 \mathrm{M}$ elution fraction & 10 & + & + & + & + & + \\
\hline Others' elution fraction & 80 & - & - & - & - & - \\
\hline \multicolumn{7}{|l|}{ WGA-lectin column } \\
\hline Bound fraction & 2 & + & + & + & + & + \\
\hline Unbound fraction & 8 & - & - & - & - & - \\
\hline \multicolumn{7}{|l|}{ Anti- $\beta_{3}$ column } \\
\hline Bound fraction & 0.1 & + & + & - & - & - \\
\hline Unbound fraction & 1.9 & + & + & + & + & + \\
\hline
\end{tabular}

Symbols: + , extract capable of blocking rounding effects of anti-GP140 antiserum; -, extract does not block rounding effect of anti-GP140 antiserum. 

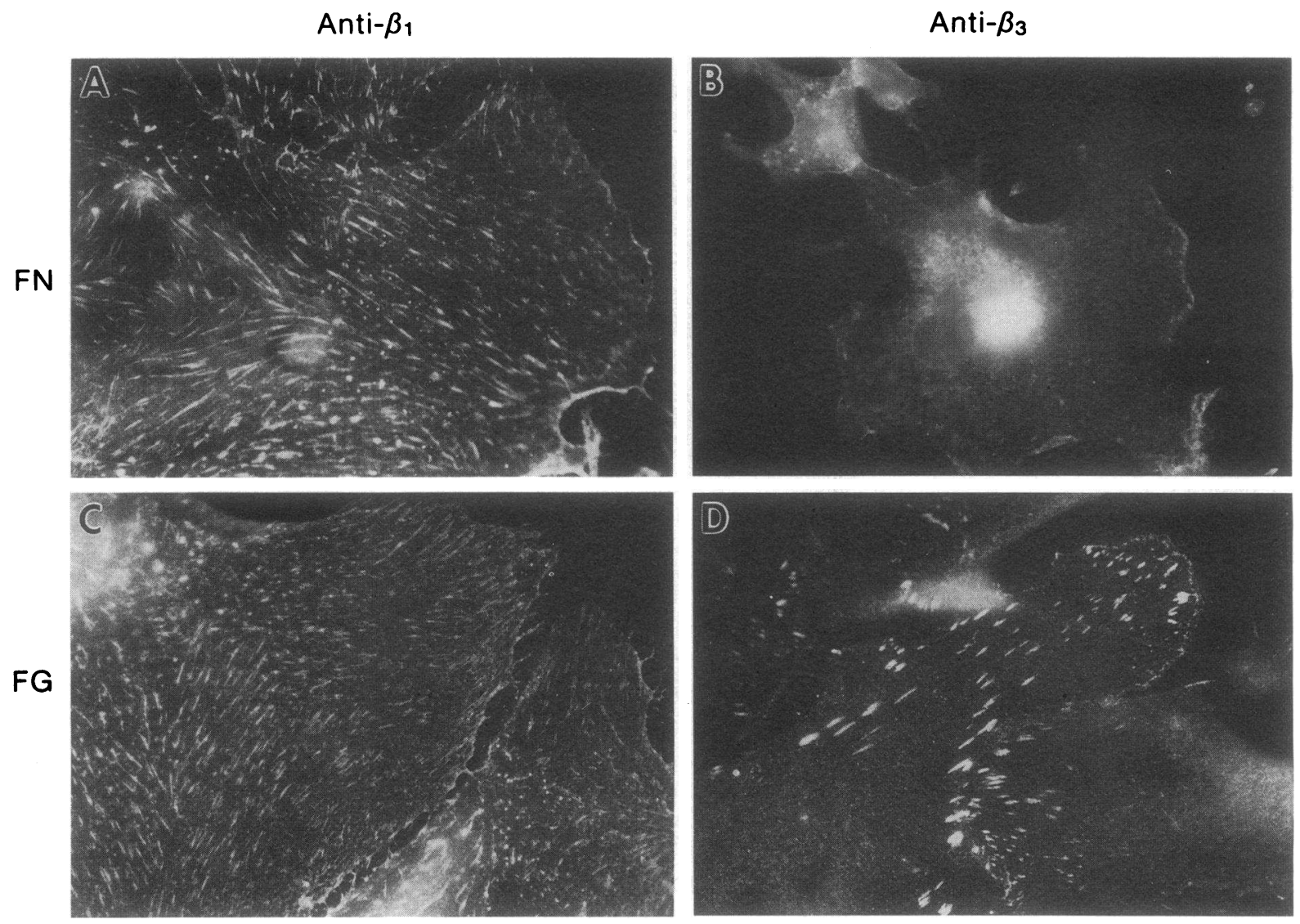

Figure 8. Immunofluorescence localization of integrin adhesion receptors on EC. Adult human large-vessel endothelial cells were plated on coverslips coated with fibronectin $(F N)(A$ and $B)$ or fibrinogen $(F G)(C$ and $D)$ in serum-free medium for $3 \mathrm{~h}$, fixed, permeabilized, and stained with a monoclonal antibody directed against the $\beta_{1}$ subunit of Integrin $(A$ and $C)$ or a monoclonal antibody directed against the $\beta_{3}$ subunit $(B$ and $D$ ). The cells were then counterstained with FITC-anti-mouse antibodies and photographed through a microscope equipped for epifluorescence $(\times 1,600)$. The anti- $\beta_{1}$ antibody $(A$ and $C)$ identifies discontinuous fibrillar structures which follow the distribution of stress fibers on both substrates. The anti- $\beta_{3}$ antibody stains discreet areas on the periphery of the cell that correspond to adhesion plaques when cells are plated on fibrinogen $(D)$ but not on fibronectin $(B)$.

$150 / 95-\mathrm{kD}$ complex plays a major role in $\mathrm{EC}$ adhesion to fibrinogen and gelatin, but other receptors are involved in the adhesion to fibronectin, laminin, and collagen.

Distribution of adhesion receptors on $E C$. The distribution of ECM receptors on EC cells was examined by fluorescence microscopy. To determine which receptors the EC would utilize when presented with defined substrata, the cells were plated in the presence or absence of cyclohexamide (to suppress endogenous fibronectin production), in serum-free medium on wells coated with fibronectin, fibrinogen, and, in some cases, collagen and laminin. After $3 \mathrm{~h}$, cells were fixed and stained with monoclonal antibodies specific for either $\beta_{1}$ or $\beta_{3}$ integrin subunits.

When cells were plated onto coverslips coated with fibronectin or fibrinogen and subsequently stained with an antibody specific for the $\beta_{1}$ subunit of the fibronectin receptor, a pattern such as that shown in Fig. 8, $A$ and $C$, was obtained. Immunofluorescence was seen in thin filamentous arrangements along the ventral cell surface. This pattern closely followed the actin-containing stress fibers found in these cells (data not shown). This pattern also resembled, in both shape and distribution, that seen when these same cells were stained with anti-fibronectin antibodies (Fig. $9 \mathrm{~B}$ ). In contrast, when EC plated on fibronectin were stained with antibodies specific for the $\beta_{3}$ subunit of the fibrinogen receptor, there were no adhesive structures noted (Fig. $9 \mathrm{~B}$ ). However, if cells were plated on fibrinogen and stained with anti- $\beta_{3}$ antibodies, welldefined focal contactlike structures were noted at the cells periphery (Fig. $8 \mathrm{D}$ ). These receptors were different in both distribution and shape from those noted when cells were stained with anti- $\beta_{1}$ antibodies (compare Fig. 8, $A$ and $C$, with $D$ ).

These data showed that the $\beta_{3}$-containing receptors were only organized by the cell in response to exposure to the appropriate ECM. The codistribution of the $\beta_{1}$-containing receptors and cellular fibronectin suggested that the appearance of adhesive structures on cells plated on fibrinogen was due to the presence of fibronectin produced by these cells. To test this possibility, cells were plated on fibrinogen in the presence and absence of cyclohexamide to inhibit endogenous protein synthesis. In the absence of cycloheximide, these cells produced fibronectin as detected by anti-fibronectin antibodies (Fig. 9 $B$ ). They also organized their $\beta_{1}$-containing subunits into the thin, fibrous adhesive structures (Fig. $9 A$ ). In the presence of cycloheximide, however, there were few, if any, adhesive structures formed which contained $\beta_{1}$ subunits (Fig. $9 C$ ) and similarly, little fibronectin was detected (Fig. 9 D). Cells stained with anti- $\beta_{3}$ antibodies in the presence of cycloheximide showed adhesive structures exactly like those noted in 

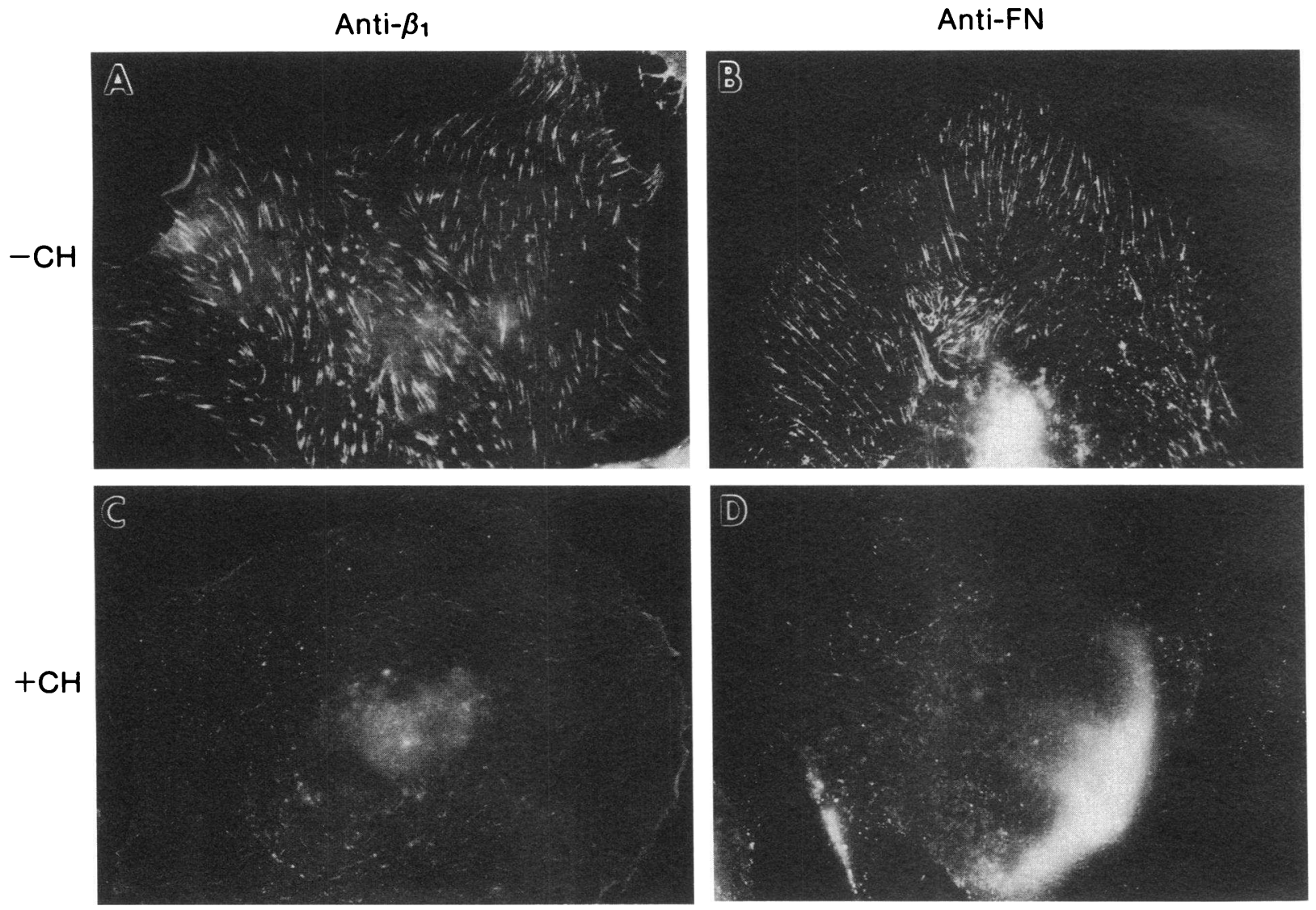

Figure 9. Importance of endogenous EC fibronectin $(F N)$ production in integrin receptor organization. Adult human large-vessel EC were plated on coverslips coated with fibrinogen $(F G)$ in serum-free medium for $3 \mathrm{~h}$ in the absence $(A$ and $B)$ or presence $(C$ and $D)$ of $25 \mu \mathrm{g} / \mathrm{ml} \mathrm{cy-}$ cloheximide $(\mathrm{CH})$ to prevent endogenous FN production by the EC. The cells were then fixed, permeabilized, and stained with a monoclonal antibody directed against the $\beta_{1}$ subunit of integrin $(A$ and $C)$ followed by counterstaining with FITC-anti-mouse antibodies or stained with a polyclonal antiserum produced against human FN $(B$ and $D)$ followed by counterstaining with rhodamine-anti-goat antibodies. The cells were photographed through a microscope equipped for epifluorescence $(\times 1,600)$. In the absence of $\mathrm{CH}$, the anti- $\beta_{1}$ antibody identifies discontinuous fibrils $(A)$ that colocalize with the fibronectin fibrils produced by the EC $(B)$. The addition of $\mathrm{CH}$ markedly inhibits the production of FN fibrils $(D)$. This change is associated with the virtual elimination of staining with the anti- $\beta_{1}$ antibody $(C)$, suggesting that the organization of fibronectin receptors only occurs when endogenous $\mathrm{FN}$ is present.

Fig. $8 D$. Thus, EC cells appear to organize their ECM receptors in response to specific ECM molecules and different receptors are organized in characteristic patterns along the ventral cell surface.

Since cells are not normally presented with one clearly defined choice of substrate, and since serum is normally present during cell growth, we repeated the above experiments in the presence of serum after $24 \mathrm{~h}$ in culture. The morphology of the adhesive structures, as well as their distribution, was exactly like that seen in Fig. 8 on all substrates. The $\beta_{1}$-containing receptors localized exclusively to fibrillar structures and the fibrinogen receptors were found in broad, brush strokelike structures localized at the cell periphery or at the leading lamella.

\section{Discussion}

We have used a combination of polyclonal and monoclonal antibodies to determine the repetoire of cell-substratum adhesion receptors expressed by human EC. The polyclonal antiGP140 antibodies, which disrupt EC adhesion to fibronectin, fibrinogen, collagen, laminin, and gelatin, immunoprecipi- tated a set of proteins ranging in molecular mass from 150 to $95 \mathrm{kD}$. Differential immunoprecipitation with a series of monoclonal antibodies reactive with specific subunits of members of the integrin superfamily (Table I) revealed that the anti-GP140 immunoprecipitates contained a mixture of integrins. The results are summarized in Fig. 10. Based upon the proposed composition of the Integrin family of ECM receptors (8), human EC contain (a) a GP IIb/IIIa-like receptor similar to the vitronectin receptor which binds to fibrinogen and consists of a $150-\mathrm{kD} \alpha_{\mathrm{v}}$ subunit and a $95-\mathrm{kD} \beta_{3}$ subunit, $(b)$ a fibronectin receptor consisting of a $150-\mathrm{kD} \alpha_{5}$ subunit and a 125-kD $\beta_{1}$ subunit, (c) a VLA-2, "class II" receptor (41) thought to be specific for collagen consisting of a $150-\mathrm{kD} \alpha_{2}$ subunit and a $125-\mathrm{kD} \beta_{1}$ subunit, (d) a multifunctional receptor (reacting with collagen, laminin, and fibronectin) similar to VLA-3, the "class I" extracellular matrix receptor (41), and the avian integrin receptor (11) consisting of a $150-\mathrm{kD} \alpha_{3}$ subunit and a $125-\mathrm{kD} \beta_{1}$ subunit. Thus, the $150-\mathrm{kD}$ material in the immunoprecipitates of the adhesion-disrupting antibodies is clearly a mixture of ECM receptor $\alpha$ subunits while the other proteins represent various integrin $\beta$ subunits. The $110-\mathrm{kD}$ band identified by the polyclonal antisera may represent a 
$150 \mathrm{kD}$

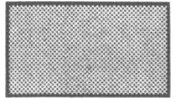

$125 \mathrm{kD}$
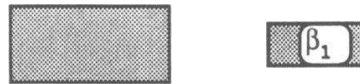

$110 \mathrm{kD}$

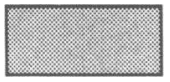

$95 \mathrm{kD}$

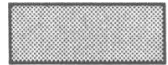

NAMES

\section{$\alpha_{2}$}

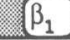

\begin{tabular}{ll}
\hline & \multicolumn{1}{c}{ Complex } \\
& \\
Substrate & $\begin{array}{l}\text { FN } \\
\text { fibrinogen } \\
\text { laminin }\end{array}$ \\
& $\begin{array}{l}\text { collagen } \\
\text { gelatin }\end{array}$
\end{tabular}

$\begin{array}{lll}\text { VLA-2 } & \text { VLA -3 } & \text { VLA -5 } \\ \text { Class II } & \text { Class I } & \text { Class VI } \\ \text { ECMr } & \text { ECMr } & \text { ECMr }\end{array}$

GP Ia/IIa

GP Ic/IIa

collagen

avian

integrin

receptor

collagen

laminin

FN
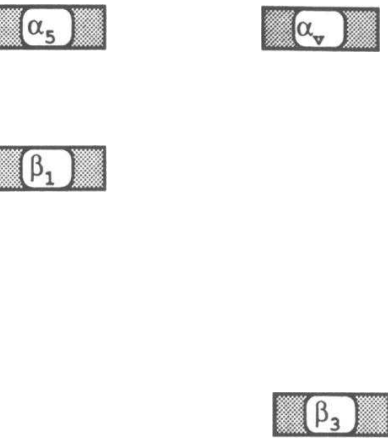

ECMr

fibronectin

receptor

FN
GP IIb/IIIa-like
"vitronectin" receptor

fibrinogen vitronectin vWF
Figure 10. Schematic representation of the results of immunoprecipitation and immunoadsorption experiments. The adhesion-disrupting polyclonal antibodies identified an EC adhesion complex consisting of glycoproteins migrating at the 150-, 125-, 110-, and $95-\mathrm{kD}$ regions of the gel. This complex is composed of at least four previously characterized extracellular matrix adhesion receptors including (a) a collagen receptor, (b) a promiscuous receptor that binds to collagen, laminin, and fibronectin, (c) a fibronectin receptor, and $(d)$ a GPIIb/IIIa-like receptor which binds to fibrinogen. precursor to the $\beta_{1}$ subunit as observed by us in avian fibroblasts (45) and by others in human fibroblasts (46), or may possibly be a previously unidentified $\beta$ subunit.

The receptor composition of different types of adult and fetal human EC was also examined. Receptor composition was not affected by the time spent in culture as evidenced by the similarity of integrins identified on primary umbilical vein EC vs. those that had been passaged many times. Furthermore, the distribution of adhesion receptors on EC derived from fetal tissue was quite similar to the composition of receptors in adult EC. In general, we found that the integrin receptor composition of adult human large vessels and fat capillaries was similar. The only difference appeared to be that the capillaries contained a relatively smaller amount of the specific collagen receptor $\left(\alpha_{2} / \beta_{1}\right)$ compared with the multifunctional receptor $\left(\alpha_{3} / \beta_{1}\right)$ than did large-vessel EC (see Fig. 4). The significance of this finding remains to be determined. It appears unlikely that the differences in EC cell morphology or behavior on various substrates $(47,48)$ can be explained on the basis of changes in the integrin composition of these cells.

The role of these receptors in EC adhesion was confirmed independently after the biochemical fractionation of nonionic detergent extracts of EC. Monoclonal affinity chromatography made it possible to isolate the GPIIb/IIIa-like receptor. This purified material blocked the effect of anti-GP140 only on EC plated on gelatin or fibrinogen, not on cells plated on other substrates. The ability of the material that passed through the anti- $\beta_{3}$ monoclonal antibody column (containing only ECM receptors from the $\beta_{1}$ integrin family) to block the effect of anti-GP140 on cell adhesion to fibronectin, collagen, and laminin argues for the role of this family of integrin receptors in binding to these ECM molecules. It is interesting that this material also blocked the effects of the anti-GP140 on fibrinogen. This may be due to a residual $\beta_{3}$-containing receptor in this preparation or it may indicate that fibrinogen is also a substrate for a $\beta_{1}$-containing integrin (possibly the multifunctional $\alpha_{3} / \beta_{1}$ receptor). The reactivity of the anti-GP140 polyclonal antibody with multiple adhesion receptors probably explains its potent biological activity in a wide variety of cell types $(36,37)$ and on a wide range of substrates.

Immunofluorescence techniques were used to examine the cellular distribution of these receptors. There were clear differences in the localization of Integrins containing the $\beta_{1}$ vs. $\beta_{3}$ subunit. The $\beta_{3}$ subunit-containing receptors were fewer in number and appeared in broad brush strokelike patterns usually nearer the periphery of the cells (Fig. 8). The distribution is characteristic of focal contacts (38). The receptors stained by the anti- $\beta_{1}$ monoclonal antibody were more numerous, were found along the entire length of stress fibers, and were finer in morphology, varying from thin brush strokelike structures near the stress fiber termini to thin filamentlike structures found along the length of stress fibers (Fig. 8). This distribution is similar to that described by others (49-51) who have found that the predominant organizational arrangement of the $\beta_{1}$ subunit-containing receptors is a more linear pattern, aligning with cytoskeletal stress fibers.

The question arises as to which adhesion receptors a cell utilizes when forced to adhere to a defined substratum. It is clear that during initial adhesive events under serum-free conditions, cells organize the IIb/IIIa-like receptor (identified with the anti- $\beta_{3}$ monoclonal antibody) into focal contacts only in the presence of the specific ligands such as vitronectin (50-52) or fibrinogen (25, this study). No focal contacts were stained with anti- $\beta_{3}$ subunit antibodies on cells plated on fibronectin, 
laminin, or collagen. Our results support the hypothesis suggested by others $(22,24,25)$ that the endothelial cell "vitronectin" receptor is also involved in the initial adhesion of endothelial cells to fibrinogen.

While it is clear that the organization of the $\beta_{3}$ subunit receptor is substrate-specific, some controversy exists about the distribution of $\beta_{1}$ subunit-containing receptors under serum-free conditions on specific substrates. Dejana et al. (51) and Fath et al. (52) have found that fibronectin receptors are not organized into recognizable structures in cells plated, onto vitronectin in serum-free medium. In contrast, the data of Singer et al. (50) show organized arrangements of $\beta_{1}$-containing receptors (in elongated focal contactlike structures) on cells plated on fibronectin and vitronectin. Our results support the hypothesis that the organization of the $\beta_{1}$ subunit receptors is substrate-specific. Although we observed fibrillar structures staining with anti- $\beta_{1}$ subunit monoclonal antibody on cells plated in serum-free media on fibrinogen (Fig. $9 \mathrm{~A}$ ), we believe that this pattern was due to localization of receptors over endogenously produced fibronectin fibrils (Fig. 9 B). By exposing the cells to cyclohexamide, which prevented the formation of fibronectin fibrils (Fig. $9 \mathrm{D}$ ), we were able to eliminate most of the fibrillar staining with the anti- $\beta_{1}$ antibody (Fig. $9 C$ ). These results emphasize the importance of matrix proteins produced by the cells in organizing their own adhesion receptors.

As EC adhesion is further dissected, it must be kept in mind that this is a complex event involving several different receptors, each of which may predominate at different times. Data are accumulating which indicate that there is more than one binding site on the fibronectin molecule (53), and that cooperative interaction of receptors at other binding sites on the molecule may be important for cell attachment, spreading, and locomotion (54). The finding that both anti-GP140's were ineffective in blocking initial adhesion of endothelial cells to fibronectin or collagen, but could effectively detach cells from the various substrates after $18 \mathrm{~h}$, supports the idea that the receptor responsible for initial attachment to fibronèctin or collagen may be different from the receptor responsible for the spreading and the maintenance of adhesion to these strates. Alternatively, the antibody may not block the binding or clustering of receptors in the presence of ECM molecules, but may interfere with the organization of receptors into adhesion structures required for cell spreading. Neural cells also show this difference in sensitivity of initial adhesive event and cellspreading to disrupting agents (54).

In the blood vessel, some or all of these receptors may act in concert to maintain the integrity of the vascular lining against stress, while during the processes of cell migration or vascular development, one or the other of these receptors may be of predominant importance. As we begin to look more closely at the process of EC adhesion, it will be important to determine this hierarchy of receptor function, the molecular organization of these receptors, as well as whether they are involved in the generation of signals required for the control of cell behavior or division.

\section{Acknowledgments}

The authors would like to thank Drs. Joel Bennet, William Carter, Martin Hemler, James Hoxie, R. L. Juliano, Hynda Kleinman, Elizabeth Wayner, and Stuart Williams for their generous gifts of reagents;
Dr. A. P. Fishman for his support and encouragement; Mr. Curtis Altman for technical assistance, and Ms. Marie Lennon for skillful preparation of this manuscript.

This work was supported by grants HL-01587 and HL-08805 (Dr. Albelda), HL-34153 (Dr. Levine), and HL-39023 (Dr. Buck) from the National Heart, Lung and Blood Institute, grant AG-04861 (Dr. Levine) from the National Institute on Aging, and grants CA-19144, and CA-10815 from the National Cancer Institute (Dr. Buck).

\section{References}

1. Fishman, A. P. 1982. Endothelium: a distributed organ of diverse capabilities. Ann. NY Acad. Sci. 401:1-8.

2. Houdikj, W. P. M., and J. J. Sixma. 1985. Fibronectin in artery subendothelium is important for platelet adhesion. Blood. 65:598604.

3. Clark, R. A. F., J. M. Folkvord, and L. D. Nielsen. 1986. Either exogenous or endogenous fibronectin can promote adherence of human endothelial cells. J. Cell Sci. 82:263-280.

4. Dejana, E., S. Colella, L. R. Languino, G. Balconi, G. C. Corbascio, and P. C. Marchisio. 1987. Fibrinogen induces adhesion, spreading and microfilament organization of human endothelial cells in vitro. J. Cell Biol. 104:1403-1411.

5. Form, D. M., B. M. Pratt, and J. A. Madri. 1986. Endothelial cell proliferation during angiogenesis: in vitro modulation by basement membrane components. Lab. Invest. 55:521-530.

6. Gospodarowicz, D., and G. M. Lui. 1981. Effect of substrata and fibroblast growth factor on the proliferation in vitro of bovine aortic endothelial cells. J. Cell. Physiol. 109:69-81.

7. Macarak, E. J., and P. S. Howard. 1983. Adhesion of endothelial cells to extracellular matrix proteins. J. Cell. Physiol. 116:76-86.

8. Hynes, R. O. 1987. Integrins: a family of cell surface receptors. Cell. 48:549-554.

9. Buck, C. A., and A. F. Horwitz. 1987. Cell surface receptors for extracellular matrix molecules. Annu. Rev. Cell Biol. 3:179-205.

10. Ruoslahti, E., and M. D. Pierschbacher. 1987. New perspectives in cell adhesion: RGD and integrins. Science (Wash. DC). 238:491-497.

11. Buck, C. A., and A. F. Horwitz. 1987. Integrin, a transmembrane glycoprotein complex mediating cell-substratum adhesion. $J$. Cell Sci. 8(Suppl.):231-250.

12. Pytela, R., M. D. Pierschbacher, and E. Ruoslahti. 1985. Identification and isolation of a $140 \mathrm{kD}$ cell surface glycoprotein with properties expected of a fibronectin receptor. Cell. 40:191-198.

13. Brown, P. J., and R. L. Juliano. 1986. Expression and function of a putative cell surface receptor for fibronectin in hamster and human cell lines. J. Cell Biol. 103:1595-1603.

14. Gehlsen, K. R., L. Dillner, E. Engvall, and E. Ruoslahti. 1988. The human laminin receptor is a member of the integrin family of cell adhesion receptors. Science (Wash. DC). 241:1228-1229.

15. Wayner, E. A., and W. G. Carter. 1987. Identification of multiple cell adhesion receptors for collagen and fibronectin in human fibrosarcoma cells possessing unique $\alpha$ and $\beta$ subunits. J. Cell Biol. 105:1873-1884.

16. Hemler, M. E., C. Huang, and L. Schwarz. 1987. The VLA protein family. J. Biol. Chem. 262:3300-3309.

17. Ginsberg, M. H., J. Loftus, J. J. Ryckwaert, M. Pierschbacher, M. Pytela, R. Ruoslahti, and E. Plow. 1987. Immunochemical and $\mathrm{N}$-terminal sequence comparison of two cytoadhesins indicates they contain similar or identical beta subunits and distinct alpha subunits. J. Biol. Chem. 262:5437-40.

18. Springer, T. A., M. L. Dustin, T. K. Kishimoto, and S. D. Marlin. 1987. The lymphocyte function-associated LFA-1, CD2, and LFA-3 molecules: cell adhesion receptors of the immune system. 1987. Annu. Rev. Immunol. 5:223-52.

19. Phillips, D. R., I. F. Charo, L. V. Parise, and L. A. Fitzgerald. 1988. The platelet membrane glycoprotein IIb-IIIa complex. Blood. 71:831-843. 
20. Pytela, R., M. D. Pierschbacher, and E. Ruoslahti. 1985. A $125 / 115 \mathrm{kDa}$ cell surface receptor specific for vitronectin interacts with the arginine-glycine-aspartic acid adhesion sequence derived from fibronectin. Proc. Natl. Acad. Sci. USA 82:5766-5770.

21. Charo, I. F., L. A. Fitzgerald, B. Steiner, S. C. Rall, L. S. Bekeart, and D. R. Phillips. 1986. Platelet glycoproteins IIb and IIIa: evidence for a family of immunologically and structurally related glycoproteins in mammalian cells. Proc. Natl. Acad. Sci. USA. 82:83518355.

22. Charo, I. F., L. S. Beakeart, and D. R. Phillips. 1987. Platelet glycoprotein IIb/IIIa-like proteins mediate endothelial cell attachment to adhesive proteins and the extracellular matrix. J. Biol. Chem. 262:9935-9938.

23. Chen, C. S., P. Thiagarajan, S. M. Schwartz, J. M. Harlan, and R. L. Heimark. 1987. The platelet glycoprotein IIb/IIIa-like protein in human endothelial cells promotes adhesion but not initial attachment to extracellular matrix. J. Cell Biol. 105:1885-1892.

24. Cheresh, D. A. 1987. Human endothelial cells synthesize and express an Arg-Gly-Asp-directed adhesion receptor involved in attachment to fibrinogen and von Willebrand factor. Proc. Natl. Acad. Sci. USA 84:6471-6475.

25. Dejana, E., L. R. Languino, S. Colella, G. C. Corbascio, E. Plow, M. Ginsberg, and P. C. Marchisio. 1988. The localization of a platelet Gp IIb-IIIa-related protein in endothelial cell adhesion structures. Blood. 71:566-572.

26. Fitzgerald, L. A., I. F. Charo, and D. R. Phillips. 1985. Human and bovine endothelial cells synthesize membrane proteins similar to human platelet glycoproteins IIb and IIIa. J. Biol. Chem. 160:1089310896.

27. Leeksma, O. C., J. Zandvergen-Spaargaren, J. C. Giltay, and J. A. van Mourik. 1986. Cultured human endothelial cells synthesize a plasma membrane protein complex immunologically related to the platelet glycoprotein IIb/IIIa complex. Blood. 67:1176-1180.

28. Newman, P. J., Y. Kawai, R. R. Montgomery, and T. J. Kunicki. 1986. Synthesis by cultured human umbilical vein endothelial cells of two proteins structurally and immunologically related to platelet membrane glycoproteins IIb and IIIa. J. Cell Biol. 103:81-86.

29. Thiagarajan, P., S. S. Shapiro, E. Levine, L. DeMarco, and A. Yalcin. 1985. A monoclonal antibody to human platelet glycoprotein IIIa detects a related protein in cultured human endothelial cells. $J$. Clin. Invest. 75:896-901.

30. Jarrell, B., E. Levine, S. Shapiro, S. Williams, R. A. Carabasi, S. Mueller, and S. Thornton. 1984. Human adult endothelial cell growth in culture. J. Vasc. Surg. 1:757-764.

31. Thornton, S. C., S. N. Mueller, and E. M. Levine. 1983. Human endothelial cells: use of heparin in cloning and long-term serial cultivation. Science (Wash. DC). 222:623-625.

32. Maciag, T., G. A. Hoover, M. B. Stemmerman, and R. Weinstein. 1981. Serial propagaton of human endothelial cells in vitro. $J$. Cell Biol. 91:410-416.

33. Rupnick, M. A., A. Carey, and S. K. Williams. 1988. Phenotypic diversity in cultured cerebral microvascular endothelial cells: in vitro cell. Dev. Biol. 24:435-444.

34. Rosen, E. M., J. P. Noveral, S. N. Mueller, and E. M. Levine. 1985. Regulation of angiotensin I-coverting enzyme activity in serially cultivated bovine endothelial cells. J. Cell. Physiol. 122:30-38.

35. Knudsen, K. A., P. E. Rao, C. H. Damsky, C. A. Buck. 1981. Membrane glycoproteins involved in cell-substratum adhesion. Proc. Natl. Acad. Sci. USA. 78:6071-6075.

36. Tomaselli, K. J., C. H. Damsky, and L. F. Reichardt. 1987. Interactions of a neuronal cell line (PC12) with laminin, collagen IV, and fibronectin: identification of integrin-related glycoproteins involved in attachment and process outgrowth. J. Cell Biol. 105:23472358.

37. Sutherland, A. E., P. G. Cararco, and C. H. Damsky. 1988. Expression and function of cell surface extracellular matrix receptors in mouse blastocyst attachment and outgrowth. J. Cell Biol. 106:1331-1348.
38. Damsky, C. H., K. A. Knudsen, D. Bradley, C. A. Buck, and A. F. Horwitz. 1985. Distribution of the cell-substratum attachment (CSAT) antigen on myogenic and fibroblastic cells in culture. J. Cell Biol. 100:1528-1539.

39. Brass, L. F., S. J. Shattil, T. J. Kunicki, and J. S. Bennett. 1985. Effect of calcium on the stability of the platelet membrane glycoprotein IIb/IIIa complex. J. Biol. Chem. 260:7875-7881.

40. Wayner, E. A., W. G. Carter, R. S. Piotrowicz, and T. J. Kunicki. 1988. The functions of multiple extracellular matrix receptors in mediating cell adhesion to extracellular matrix: preparation of a monoclonal antibody to the fibronectin receptor that specifically inhibits adhesion to fibronectin and reacts with platelet glycoproteins Ic/IIa. $J$. Cell. Biol. 107:1881-1891.

41. Takada, Y., E. A. Wayner, W. G. Carter, and M. E. Hemler. 1988. Extracellular matrix receptors, ECMRII and ECMRI, for collagen and fibronectin correspond to VLA-2 and VLA-3 in the VLA family of heterodimers. J. Cell. Biochem. 37:385-393.

42. Hemler, M. E., C. F. Ware, and J. L. Strominger. 1983. Characterization of a novel differentiation antigen complex recognized by a monoclonal antibody (A-1A5): unique activation-specific molecular forms on stimulated T cells. J. Immunol. 131:334-340.

43. Laemmli, U. K. 1970. Cleavage of structural proteins during the assembly of the head of bacteriophage T4. Nature (Lond.). 227:680-685.

44. Horwitz, A., K. Duggan, R. Greggs, C. Decker, and C. Buck. 1985. The cell substrate attachment (CSAT) antigen has properties of a receptor for laminin and fibronectin. J. Cell Biol. 101:2134-2144.

45. Hirst, R., A. Horwitz, C. Buck, and L. Rohrschneider. 1986. Phosphorylation of the fibronectin receptor complex in cells transformed by oncogenes that encode tyrosine kinases. Proc. Natl. Acad. Sci. USA. 83:6470-6474.

46. Roberts, C. J., T. M. Birkenmeier, J. J. McQuillan, S. K. Akiyama, S. S. Yamada, W.-T. Chen, K. M. Yamada, and J. A. McDonald. 1988. Transforming growth factor $\beta$ stimulates the expression of fibronectin and of both subunits of the human fibronectin receptor by cultured human lung fibroblasts. J. Biol. Chem. 263:4586-4592.

47. Kubota, Y., H. K. Kleinman, G. R. Martin, and T. J. Lawley. 1988. Role of laminin and basement membrane in the morphological differentiation of human endothelial cells into capillary-like structures. J. Cell Biol. 107:1589-1598.

48. Madri, J. A., and S. K. Williams. 1983. Capillary endothelial cell cultures: phenotypic modulation by matrix components. J. Cell Biol. 97:153-165.

49. Marcantonio, E. E., and R. O. Hynes. 1988. Antibodies to the conserved cytoplasmic domain of the integrin $\beta_{1}$ subunit react with proteins in vertebrates, invertebrates, and fungi. J. Cell Biol. 106:1765-1772.

50. Singer, I. I., S. Scott, D. W. Kawka, D. M. Kazazis, J. Gailit, and E. Ruoslahti, E. 1988. Cell surface distribution of fibronectin and vitronectin receptors depends on substrate composition and extracellular matrix accumulation. J. Cell Biol. 106:2171-2182.

51. Dejana, E., S. Colella, G. Conforti, M. Abbadini, M. Gaboli, and P. C. Marchisio. 1988. Fibronectin and vitronectin regulate the organization of their respective Arg-Gly-Asp adhesion receptors in cultured human endothelial cells. J. Cell Biol. 107:1215-1223.

52. Fath, K. R., C.-J. S. Edgehill, and K. Burridge. 1989. The distribution of distinct integrins in focal contacts is determined by the substrate composition. J. Cell Sci. 92:67-75.

53. Masanobu, O., M. S. Kang, and K. M. Yamada. 1988. Site-directed mutagenesis of the cell-binding domain of human fibronectin: separable, synergistic sites mediate adhesive function. Cell. 53:649657.

54. Dufour, S., J.-L. Duband, M. J. Humphries, M. Obara, K. M. Yamada, and J. P. Thiery. 1988. Attachment, spreading and locomotion of avian neural crest cells are mediated by multiple adhesion sites on fibronectin molecules. EMBO (Eur. Mol. Biol. Organ.) J. 7:26612671. 